\title{
Geotechnical and Mineralogical Evaluations of Two Major Clay Deposits in Southwestern Nigeria
}

\author{
${ }^{1}$ E.O. Odeyemi, ${ }^{2}$ O.O. Ige, ${ }^{2}$ O.D. Obasaju and ${ }^{2}$ O.O. Ogunsanwo \\ ${ }^{1}$ Landmark University, Km 4, Ipetu Road, 1001 PMB, Omu-Aran, Kwara State, Nigeria \\ ${ }^{2}$ Department of Geology and Mineral Sciences, University of Ilorin, 1515 Private Mail Bag, \\ Ilorin, Kwara State, Nigeria \\ emmanueloloruntoba1@gmail.com
}

\begin{abstract}
A total of 10 clayey samples derived from charnockite and granite from parts of Southwestern Nigeria (Ilemosho, Ekiti State and Okelele, Kwara State) were subjected to geotechnical and mineralogical tests in order to evaluate their suitability as raw materials for various engineering works. Classification tests carried out on these soils include: grain size analysis and Atterberg limits determination while improved tests include compaction, permeability and mineralogical test using XRD. The grain size analysis shows that Okelele soils (OKL1-OKL5) gravel percentage range from $2-8 \%$, percentage of sand range from $15-38 \%$, silt percentage range from $11-33 \%$, clay percentage range from $43.7-50 \%$ while Ilemesho soils (ILM1-LM5) have gravel percentage range from $1-6 \%$, percentage sand from $9-63 \%$, silt percentage range from $7-52 \%$ and clay percentage range from $14-45 \%$. The plastic limit of the soils range between $18-34 \%$, plasticity index (8-47\%); shrinkage limit (5.9-10\%); activity (0.5-1.0); soil type (normal). The MDD and $\mathrm{OMC}$ of the soils when compacted at the energy of the standard proctor gave $1.30-1.60 \mathrm{~g} / \mathrm{cm}^{3}$ and $12.0-23 \%$, respectively. The coefficient of permeability is in the order of $10^{-3}-10^{-4} \mathrm{~cm} / \mathrm{sec}$ which are in the range of impermeable soils. The soils contain no undesirable mineral that can constitute working problem in the field. The soils can be used as liners in landfill systems and to some extent as fill in dam construction and subgrade materials.
\end{abstract}

Key words: Southwestern Nigeria, Atterberg limits, grain size analysis, coefficient of permeability, Okelele soils, subgrade materials

\section{INTRODUCTION}

The term "clay" refers to a naturally occurring material that composed primarily of fine-grained minerals which is generally, plastic at appropriate water contents and susceptible to hardening when fired at high temperature (Dogan et al., 2002). Although, clay usually contains phyllosilicates, it may contain other materials that could increase plasticity when wet and also harden when fired. However, associated phases in clay may include organic matter and materials that do not increase plasticity (Bakker, 1993). Clay is formed either as a product of the chemical weathering of pre-existing granitic rocks and feldspar minerals, particularly in warm tropical and subtropical regions of the world or as a result of the hydrothermal alteration of granitic rocks (Akhirevbulu et al., 2010). The type of clay that formed is not only a function of the nature of parent rock but also the intensity of weathering and the length of time during which it occurred (Okunlola, 2008). One major precursor of clay deposits is feldspar which is a common mineral in many granitic rocks like granite, pegmatite, charnockite. In addition, clay deposits are common in areas where hydrothermal alteration leads to high level of kaolinization which characterizes area where Pan-African magmatism is prevalent (Okunlola, 2008).

Clays are undoubtedly, important in agriculture, ceramics and engineering and also have other industrial applications. The nature of clay and its composition determine not only its quality and commercial value but also, to a large extent, its engineering behaviour. Among the characteristics of clays that influence their engineering performance are clay mineral composition, physical properties such as particle size distribution, non-clay mineral composition, organic matter content and geologic history (Grim, 1968).

Several studies on clays in different part of Nigeria and the world are available in literature. Ogunsanwo (1996) carried out geotechnical investigation for some soils from Southwestern Nigeria for use as mineral seals in waste disposal landfills. Ige (2009) also carried out assessment of geotechnical properties of

Corresponding Author: E.O. Odeyemi, Landmark University, Km 4, Ipetu Road, 1001 PMB, Omu-Aran, Kwara State, Nigeria emmanueloloruntoba1@gmail.com 


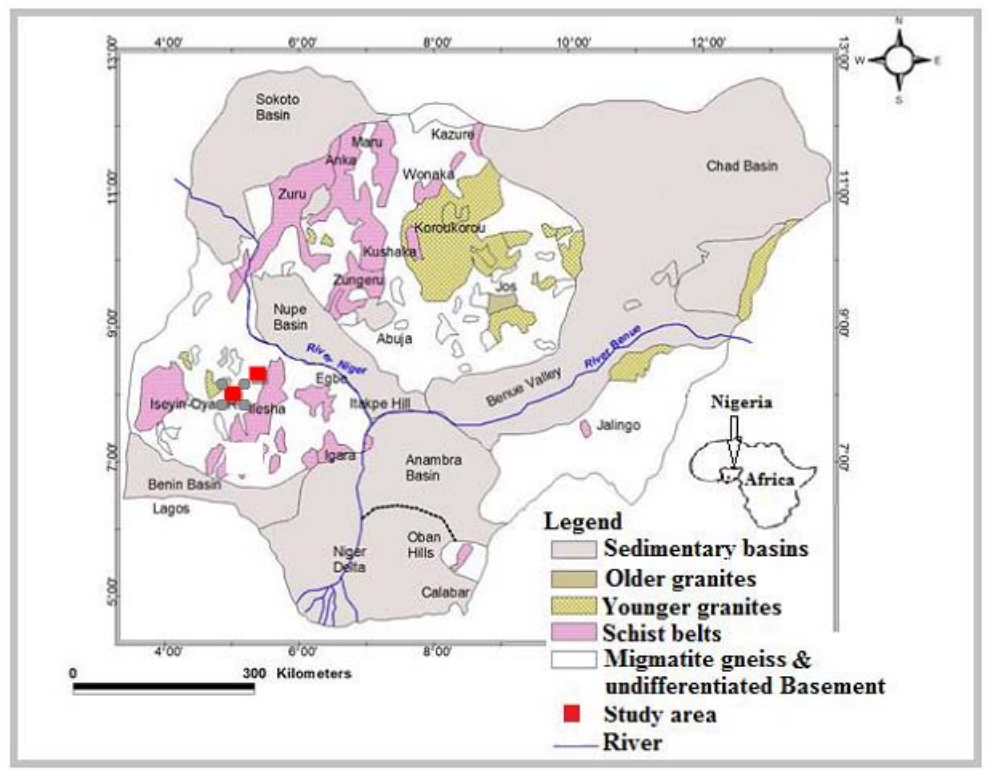

Fig. 1: Geological map of Nigeria showing the study area (modified from Nigeria Geological Survey, 1994)

migmatite-gneiss derived residual soil from Ilorin, Southwestern Nigeria as barrier in sanitary landfills. Other researches include: Irabor (2002), Odo and Nwajagu, Olokode et al. (2013), Fakolujo et al. (2012) and Akinola et al. (2014). Furthermore, Alao (1983), Nnadi (1987), Ogunsanwo (1995) and Ige et al. (2005) have investigated the mineralogical properties of clay soils in parts of Nigeria and have shown that the mineralogy of a soil has significant influence on their use as construction materials.

In recent time, the statistics of failures of structures that were initially thought to be well engineered have increased geometrically. Folagbade (2001) identified the use of inferior materials for construction as one of the major causes of failure. Also, a good number of practitioners use visual inspection and sense of touch to predict the properties of soil on site or believe that a certain soil have the same property with a previously utilized soil, since, they have the same physical appearance but have resulted into failure. It is therefore, necessary in these times of scarce resources to carry out proper geotechnical and mineralogical investigation on this very important engineering material as failure to do this may consequentially lead to loss of lives and properties of poor unsuspecting members of the public and also into waste of resources, time and labour devoted to the construction work. Thus, this research aims at evaluating the geotechnical and mineralogical properties of two major clay deposits (Ilemosho and Okelele clays in Ekiti and Ilorin, respectively) in Southwestern Nigeria for their use as industrial raw material.
The study area and environs (Fig. 1) is underlain by gneisses, granite and charnockite. The gneisses are essentially, migmatite which grade into biotite gneiss in some areas, contact relationship indicates that it is the country rock into which the other rocks are emplaced. The gneissic rock occurs as highly weathered, low-lying, denuded and poorly exposed bodies. Structural features of the rock include poorly developed foliations that are so, faint in some places and become indiscernible around West of Aiyede (Akinola et al., 2014). The granite on the other hand is mainly porphyritic in texture and is rich in biotite. Sometimes hornblende becomes prominent associated mineral and the rock grade into biotite hornblende-granite in some localities. Charnockite is more prominent in Western part of the Ilemosho area forming conspicuous massive bodies, however, smaller inselbergs of the rock occur scattered along the Southern and North central parts of the study area (Akinola et al., 2014).

\section{MATERIALS AND METHODS}

The structures, textures, colours of the soil samples were studied in the field and fresh samples were collected. Five samples were taken at Ilemosho and five at Okelele which total up to ten samples in all at intervals of approximately $5 \mathrm{~km}$ from local mining site and road cuts at depths. They were packed in neat polythene bags and labeled accordingly as ILM and OKL (Ilemosho and Okelele, respectively). The samples were air dried to remove the in situ moisture content and sent for 
laboratory analyses. Table 1 shows the parent rock, sampling localities, depth of sampling and number of samples used in this study.

The laboratory tests carried out in this study are: mineralogy using the X-Ray Diffraction method (XRD), grain size distribution using wet sieve and hydrometer, water content determination, specific gravity, bulk density and dry density, Atterberg consistency limits, compaction and permeability.

For the mineralogy examination, the powdered clay samples were spread on a glass slide and scanned at $2^{\circ} 2 \bullet / \mathrm{min}$ from $2^{\circ}-80^{\circ}$ (wavelength of 1.5406 ) using Bruker XRD D8 Advance (Model: V22.0.28) at a room temperature of $25^{\circ} \mathrm{C}$. The principle of Bragg's law was adopted and the data were then measured in reflection mode.

Table 1: Parent rock, sampling localities, depth of sampling and number of samples

\begin{tabular}{llccc}
\hline Parent rocks & $\begin{array}{l}\text { Sampling } \\
\text { localities }\end{array}$ & Symbols & $\begin{array}{c}\text { Depth of } \\
\text { sampling (m) }\end{array}$ & $\begin{array}{c}\text { No. of samples } \\
\text { evaluated }\end{array}$ \\
\hline Chamockite & $\begin{array}{l}\text { Ilemosho-Isan } \\
\text { road }\end{array}$ & ILM & $0.2-0.7$ & 5 \\
Granitic gneiss & Okelele & OKL & $1.0-2.5$ & 5 \\
\hline
\end{tabular}

All the geotechnical parameters including grain size distribution using wet sieve and hydrometer, water content determination, specific gravity, bulk density and dry density, Atterberg consistency limits, compaction and permeability were determined in accordance with the BS (1990).

\section{RESULTS AND DISCUSSION}

Particle size distribution: The results of the grain size distribution are presented in Table 2 (Fig. 2). For five samples (OKL1-OKL5) gravel percentage range from $2-8 \%$, percentage of sand range from $15-38 \%$, silt percentage range from $11-33 \%$, clay percentage range from $43.7-50 \%$. These show that the total amount of fines range from $60-79 \%$. While for the other five samples (ILM1-ILM5), gravel percentage range from 1-6\%, percentage sand from $9-63 \%$, silt percentage range from $70-52 \%$ and clay percentage range from $14-45 \%$. Thus, the total amount of fines range from $34-90 \%$. These properties show that the soils contain significant cohesive material and imply lower values of permeability. Evaluation of OKL1-OKL5 and IM1-ILM5 soil samples showed that

Table 2: Grain size distributions of the investigated soils

\begin{tabular}{|c|c|c|c|c|c|c|c|}
\hline \multirow[b]{2}{*}{ Parent materials } & \multirow[b]{2}{*}{ Symbols } & \multicolumn{5}{|c|}{ Grain size distribution (\%) } & \multirow[b]{2}{*}{ Soil groups } \\
\hline & & Gravel & Sand & Silt & Clay & Fines & \\
\hline Granite gneiss & OKL 1 & 8.0 & 17.0 & 25.0 & 50.0 & 75 & Sandy silty clay \\
\hline Granite gneiss & OKL 2 & 6.0 & 15.0 & 33.0 & 46.0 & 79 & Sandy silty clay \\
\hline Granite gneiss & OKL 3 & 2.0 & 34.0 & 20.3 & 43.7 & 64 & Silty sandy clay \\
\hline Granite gneiss & OKL 4 & 2.5 & 37.5 & 11.0 & 49.0 & 60 & Silty sandy clay \\
\hline Granite gneiss & OKL 5 & 2.0 & 38.0 & 12.5 & 47.5 & 60 & Silty sandy clay \\
\hline Chamockite & ILM 1 & 1.0 & 17.0 & 52.0 & 30.0 & 82 & Sandy clayey silt \\
\hline Chamockite & ILM 2 & 1.0 & 9.0 & 45.0 & 45.0 & 90 & Sandy clayey silt \\
\hline Chamockite & ILM 3 & 3.0 & 63.0 & 7.0 & 27.0 & 34 & Silty clayey sand \\
\hline Chamockite & ILM 4 & 6.0 & 54.0 & 26.0 & 14.0 & 40 & Clayey silty sand \\
\hline Chamockite & ILM 5 & 5.0 & 51.0 & 28.0 & 16.0 & 44 & Clayey silty sand \\
\hline
\end{tabular}

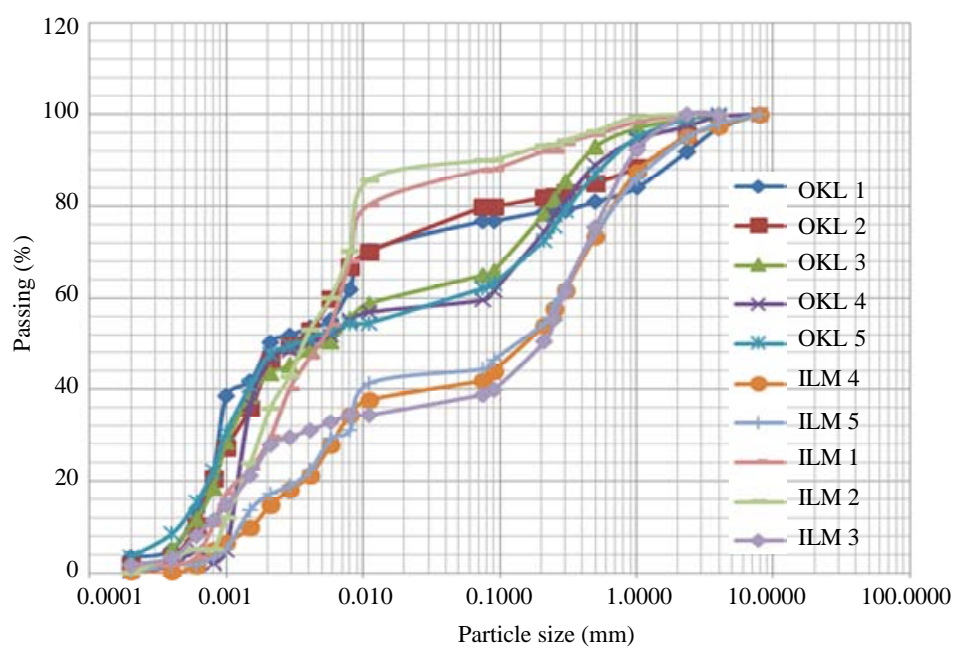

Fig. 2: Grain size distribution for the studied soil samples 
the largest grains of the soils (gravel) have diameters not $>10 \mathrm{~mm}$. The results are therefore, lower than the $\cdot 63 \mathrm{~mm}$ suggested by Onorms and values between 25 and $50 \mathrm{~mm}$ suggested by Daniel $(1991,1993)$. The implication is that the soils will have low permeability that are desirable for soils to be considered as material for mineral seal. The percentage of fines in the ten soil samples range from $34-90 \%$. This result is better than the $>15 \%$ proposed by Onorms, $>20-30 \%$ proposed by Daniel (1993) and $>20 \%$ proposed by Oeltzschner. If the percentage fines is $<15 \%$, the soils tends to become more sandy and gravely thereby making it less compactible on the field and also have higher permeability. Except for ILM3-ILM5, all the soil samples have clay percentage range between $30-50 \%$ which satisfy the $>20 \%$ suggested by Oeltzschner, $>30 \%$ recommended by Daniel (1993). All the soil samples have gravel fraction far less compare to the $<30 \%$ recommended by Daniel (1993) and $<25 \%$ by Oeltzschner and represents a compactable sand-clay mixture regardless of the parent material.

Based on the results in Table 2, using Casagrande classification, soil samples derived from granite gneiss (OKL1-OKL5) are sandy silty clay and silty sandy clay while those derived from charnockite (ILM1-ILM5) are sandy clayey silt, silty clayey sand and clayey silty sand. According to the FMWH $\cdot 35 \%$ of fine material in a soil mass is recommended to be useable as sub-base material, thus, only ILM3 sample meets this requirement. Furthermore, various researchers have affirmed that soils might be useful as landfill liners when the amount of fines is - 30\% (Daniel, 1993; Benson et al., 1994; Ige, 2009) while Oeltzschner proposed a percentage of fines $>20 \%$. All the ten soil samples satisfy these conditions and can therefore be used as landfill liners (Fig. 2).

Liquid limit: Skempton (1953) stated that in low plasticity clays the liquid limit is $<35 \%$, in intermediate plasticity clays the liquid limit ranges from $35-50 \%$ and in the high plasticity clays the liquid limit is $>50 \%$. The liquid limit values of the soil samples (Table 3), therefore, suggest that all the soils contain clays of low to intermediate plasticity. The values for all the soil samples are plotted in the standard plasticity chart (Fig. 3) and it is observed that most of the plotted values lie above the A-line which indicate that the clays in these investigated soils are essentially, inorganic.

According to Ige (2009), liquid limit is an important index property because it is correlated with various

Table 3: Atterberg limits of the studied soils and soil classification based on soil activity

\begin{tabular}{|c|c|c|c|c|c|c|c|}
\hline Symbols & Liquid limits $\left(\mathrm{W}_{\mathrm{L}} \%\right)$ & Plastic limits $\left(\mathrm{P}_{\mathrm{L}} \%\right)$ & Plasticity Indexs (PI) & Shrinkage limits $\left(\mathrm{S}_{\mathrm{L}} \%\right)$ & Clay fractions (\%) & Activities & Soil types \\
\hline OKL 1 & 68 & 25 & 43 & 10.0 & 50.0 & 0.8 & Normal \\
\hline OKL 2 & 58 & 26 & 33 & 9.3 & 46.0 & 0.7 & Normal \\
\hline OKL 3 & 68 & 21 & 47 & 9.5 & 43.7 & 1.0 & Normal \\
\hline OKL 4 & 62 & 24 & 38 & 10.0 & 49.0 & 0.8 & Normal \\
\hline OKL 5 & 65 & 22 & 43 & 10.0 & 47.5 & 0.9 & Normal \\
\hline ILM 1 & 58 & 18 & 40 & 9.3 & 30.0 & 0.8 & Normal \\
\hline ILM 2 & 52 & 34 & 18 & 8.5 & 45.0 & 0.6 & Normal \\
\hline ILM 3 & 38 & 20 & 18 & 6.2 & 27.0 & 0.5 & Normal \\
\hline ILM 4 & 34 & 26 & 8 & 5.9 & 14.0 & 0.6 & Normal \\
\hline ILM 5 & 39 & 27 & 12 & 7.8 & 16.0 & 0.7 & Normal \\
\hline
\end{tabular}

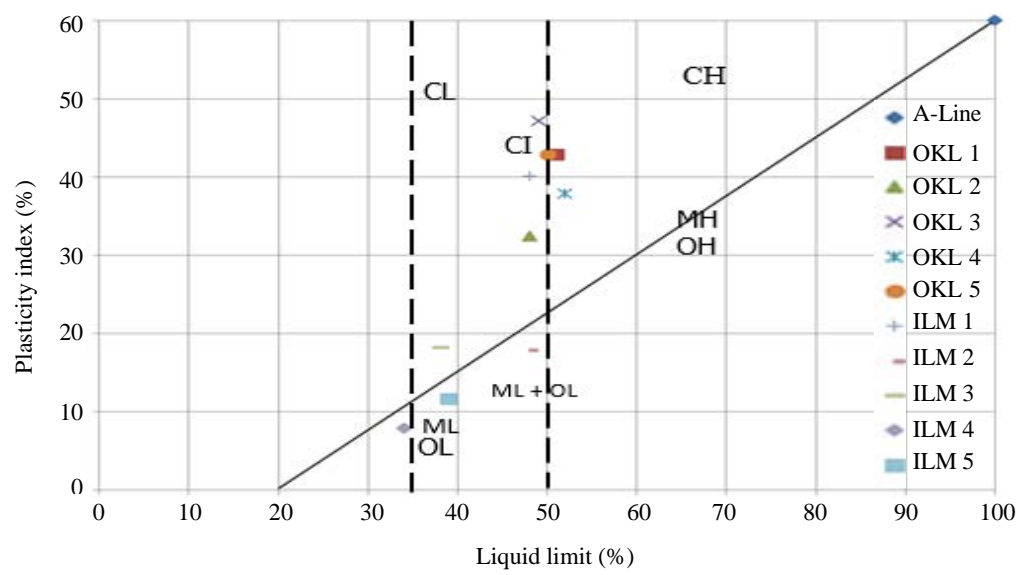

Fig. 3: Plasticity chart of the soils samples 
engineering properties. According to FMWH, subgrade/fill material should have liquid limit $\bullet 50 \%$ and plasticity index $\cdot 30 \%$ while for sub-base, liquid limit should be $\cdot 30 \%$ and plasticity index $\bullet 12 \%$. Only ILM3-ILM5 satisfy the requirement for use as subgrade/fill materials. Although, the other soils (OKL1 and ILM2) have plasticity index within the recommended value for subgrade/fill, their liquid limits are higher than the standard. Atterberg limits are also important in the selection of materials for use as liners in landfill systems. Benson et al. (1994) recommended that the liquid limit of the liner material must be at least $20 \%$. The liquid limit of all the soils are higher than the minimum required value making them suitable for barriers in landfill systems. Furthermore, there are no universally required minimum value by waste regulatory agencies for liquid limit of soils to be considered as barrier landfill (Ige et al., 2005; Ige, 2009) except that the soil should not create any working problem and that it should have low hydraulic conductivity which are characteristics of soil with high liquid limit (Ige, 2009).

Plastic Limit (PL): The observed plastic limit values for the soil samples are listed in Table 2 . It can be seen that the plastic limit values for the soils lie in between $18-35 \%$. Grim (1968) pointed out that montmorillonite and illites have higher plastic limits whereas kaolinites have generally lower values. The presence of kaolinite in the investigated soil samples may be responsible for their relatively low plastic limit values, the $\mathrm{X}$-ray diffraction results justifies this. Ugbe (2011) reported the plastic limit of $15-30 \%$ for some soils in Nigeria. The observed plastic limit values are close to the values reported by Ugbe, (2011).

Plasticity Index (PI): The plasticity index values of the soil samples are also shown in Table 2 . The values range from $8-47 \%$. Oeltzschner suggested that soils with $\mathrm{LL}>35 \%$ and $\mathrm{PI}>15 \%$ are good for consideration as mineral seals, therefore, all the soil samples except ILM4 and ILM5 are suitable for this purpose. Oeltzschner suggested $\mathrm{PI}>10 \%$, Benson et al. (1994) also suggested soil with LL of $>20 \%$, Seymour and Peacock suggested LL of $>20 \%$ and PI of $<65 \%$ for soils to be useful as liners. All the soil samples (except for ILM4 with plasticity just below 10\%) meet these requirements as liners. Soils with very high plasticity $(>70 \%$ ) become sticky when wet and form hard lumps when dry and are therefore, not workable on the field. The dry lumps, when not properly compacted, may form zones of high permeability. High plasticity values may also, cause desiccation cracking and shrinkages. None of the soil samples have such high plasticity and are thus, not expected to constitute any working problem on the field.

Shrinkage limit: The shrinkage limit values for the soil samples are listed in Table 2. The values range from $5.9-10.0 \%$. All the soil samples that range between $5.9-10.3 \%$ are consider to be soils of medium to high shrink potential according to the classification by Schedig.

Activity: The degree of plasticity of a soil with respect to its clay content is called the activity. It is estimated as the ratio of the Plasticity Index (PI) to the percentage of clay fraction $(<0.002 \mathrm{~mm}$ ) in a soil sample (Skempton, 1953). The soil samples have activity value varying between 0.6 and 1.0 and are normally active (Table 3 ).

Compaction: In any engineering construction work, compaction of soil is done to achieve a soil layer of improved engineering properties. Compaction places soils in a dense state and hence, decreases further settlement; increases shear strength and decreases permeability. The soils were compacted at the Standard Proctor energy and the two properties most important are the Maximum Dry Densities (MDD) and Optimum Moisture Contents (OMC). The former range between $1.35-1.58 \mathrm{~g} / \mathrm{cm}^{3}$ while the later range between $15.5-28.0 \%$ at Standard Proctor energy (Table 4). The OMC serves as a guide to know the

Table 4: Compaction characteristics and ratings of unified soil classification for construction (ASTM, 1557-91)

\begin{tabular}{|c|c|c|c|c|c|}
\hline \multirow[b]{2}{*}{ Locations } & \multicolumn{5}{|c|}{ Standard proctor energy } \\
\hline & $\begin{array}{l}\text { Maximum dry } \\
\text { densities }\left(\mathrm{g} / \mathrm{cm}^{3}\right)\end{array}$ & $\begin{array}{l}\text { Optimum moisture } \\
\text { contents }(\%)\end{array}$ & $\begin{array}{l}\text { Anticipated embankment } \\
\text { performances }\end{array}$ & $\begin{array}{l}\text { Value as subgrade } \\
\text { materials }\end{array}$ & Values as base course \\
\hline OKL 1 & 1.38 & 23.0 & Unsatisfactory & Poor to very poor & Not suitable \\
\hline OKL 2 & 1.30 & 22.5 & Unsatisfactory & Poor to very poor & Not suitable \\
\hline OKL 3 & 1.35 & 18.5 & Unsatisfactory & Poor to very poor & Not suitable \\
\hline OKL 4 & 1.59 & 14.0 & Poor to good & Fair to poor & Not suitable \\
\hline OKL 5 & 1.52 & 20.0 & Poor to good & Fair to poor & Not suitable \\
\hline ILM 1 & 1.48 & 21.0 & Unsatisfactory & Poor to very poor & Not suitable \\
\hline ILM 2 & 1.44 & 22.0 & Unsatisfactory & Poor to very poor & Not suitable \\
\hline ILM 3 & 1.60 & 12.0 & Poor to good & Fair to poor & Not suitable \\
\hline ILM 4 & 1.42 & 18.0 & Unsatisfactory & Poor to very poor & Not suitable \\
\hline ILM 5 & 1.40 & 18.0 & Unsatisfactory & Poor to very poor & Not suitable \\
\hline
\end{tabular}


amount of water required during construction. Thus, OKL1 requires the highest water content on the field to achieve maximum dry density at standard energy of compaction. At standard energy of compaction, the MDD values of the soils are generally lower than $1.7 \mathrm{t} / \mathrm{m}^{3}$ stipulated in Onorms did not fall within the $1.713-1.820 \mathrm{t} / \mathrm{m}^{3}$ obtained from some Nigerian soils by Ogunsanwo (1996) and $1.74 \mathrm{t} / \mathrm{m}^{3}$ recommended by Kabir and Taha for mineral seals. It is however, not to say that the soil is altogether not useful for this purpose but needs to be compacted with the energy of the modified proctor for higher values of MDD. From the values of MDD and OMC obtained, when compared with the ratings of the unified soil classification for construction, it can be deciphered that only samples OKL4, OKL5 and ILM3 have poor to good anticipated embankment performance, a fair to poor performance as subgrade material. The other samples have unsatisfactory anticipated embankment performance, poor to very poor values as subgrade material. None of the samples is suitable as base course for construction. The suitability of these soils, however can be enhanced when compacted at the energy of the modified proctor.

Permeabilty: The permeability of soil is one of the most important properties that comes into consideration during its application as liners in landfill system and fill materials in water retaining structures such as dam. The permeability coefficients of the soil samples are presented in Table 5. In general, the permeability values of the soils lie within a range of $\mathrm{k}=10^{-3}-10^{-4} \mathrm{~cm} / \mathrm{sec}$. The $\mathrm{k}$ values of the studied soils also fall within the range termed practically impermeable soils $\left(10^{-5}-10^{-7} \mathrm{~m} / \mathrm{sec}\right)$ by Lambe and Whiteman (1969). Various researchers have suggested a maximum coefficient of permeability value $1 \times 10^{-9} \mathrm{~m} / \mathrm{sec}$ for landfill barrier soils (Daniel, 1993; Rowe et al., 1995). Based on these recommendations, the soils have $\mathrm{k}$ values ideal for a liner material in landfill system.

Mineralogy: From the XRD results (Table 6), it is evident that the analyzed soil samples do not differ greatly in their mineral types. Generally, the minerals identified in the soils include kaolinite, muscovite, montmorillonite, illite, chlorite, ilmenite and some non-clay minerals, mainly quartz, feldspar, anatse and calcite. The mineralogy of the soil showed that they contain no undesirable mineral constituent. Illite, although, present in all the soils is intermediate in terms of activity and they possess threat to form swelling clays, if a favourable non-drainage and alkali condition persist. The extent of weathering can be ascertained from the mineralogy of the
Table 5: Coefficient of permeability of the studied soils

\begin{tabular}{lc}
\hline Sample symbols & Permeabilities $(\mathrm{m} / \mathrm{sec})$ \\
\hline OKL 1 & $9.014 \times 10^{-4}$ \\
OKL 2 & $9.111 \times 10^{4}$ \\
OKL 3 & $9.174 \times 10^{4}$ \\
OKL 4 & $9.037 \times 10^{4}$ \\
OKL 5 & $9.023 \times 10^{4}$ \\
ILM 1 & $9.043 \times 10^{4}$ \\
ILM 2 & $9.779 \times 10^{4}$ \\
ILM 3 & $1.016 \times 10^{-3}$ \\
ILM 4 & $1.184 \times 10^{-3}$ \\
ILM 5 & $1.093 \times 10^{-3}$ \\
\hline
\end{tabular}

Table 6: Average percentage composition of minerals in the soils

\begin{tabular}{lcc}
\hline Minerals & Okelele soils & Ilemesho soils \\
\hline Kaolinite & 26.00 & 26.87 \\
Illite & 22.59 & 25.09 \\
Chlorite & 20.71 & 17.56 \\
Muscovite & 20.22 & 17.84 \\
Quartz & 07.64 & 08.74 \\
Feldspar & 02.17 & 03.01 \\
Montmorillonite & 00.22 & 00.24 \\
Anatse & 00.21 & 00.17 \\
Ilmenite & 00.14 & 00.21 \\
Calcite & 00.11 & 00.26 \\
\hline
\end{tabular}

clays. The presence of feldspars is an indication that there can be further, alteration to form kaolinite. Grim (1968) mentioned that the PI values for kaolinites range from $1-40 \%$ with usual values of about $25 \%$, for illites, it range from $23-50 \%$ while montmorillonites have higher values. The observed plasticity index values are consistent with high kaolinitic content. The XRD results strongly support the presence of kaolinite mineral in the analyzed soil samples.

\section{CONCLUSION}

From the study of the geotechnical and mineralogical properties of these soils, the following conclusions can be drawn: the soils are generally fine grained consisting of sandy silty clay and clayey silty sand. Most of the soils are inorganic clay with low to intermediate plasticity. All the ten soil samples satisfy the condition of fines $\cdot 30 \%$ proposed by several researchers for landfill liners. From the values of MDD and OMC obtained from the standard energy of compaction, only samples OKL4, OKL5 and ILM3 can be considered for embankment purpose and assubgrade material. All the soil samples have coefficient of permeability $(\mathrm{k})$ values in order of $10^{-3}-10^{4} \mathrm{~cm} / \mathrm{sec}$ which indicates that the soils are 'very low' to impervious. It is considered that such practically impermeable soils may be useful as fill materials in dam constructions. The soils have k-values ideal for a liner material in landfill system. The mineralogy of the soil showed that they contain no undesirable mineral constituent. However, if a non-drainage and alkali condition persist, illite may constitute treat as it can weather to form swelling clays. 
The soils can found application in general civil engineering works, especially, in ceramics, landfill materials, liners and pottery.

\section{RECOMMENDATIONS}

Since, engineering and mineralogical properties of soils are influenced by several factors and vary from place to place, routine sampling and analysis is recommended. The result of these will provide updated information about the soil competence from these areas and their suitability for construction purpose. It is recommended that where these soils are found to fall short of the minimum standard, methods of soil improvement such as compaction at higher energy of modified proctor should be employed to improve their properties and usefulness.

\section{ACKNOWLEDGEMENT}

The researchers wish to thank Mr Femi, Department of Civil Engineering, University of Ilorin for laboratory assistance.

\section{REFERENCES}

Akhirevbulu, O.E., C.V.O. Amadasun, M.I. Ogunbajo and O. Ujuanbi, 2010. The geology and mineralogy of clay occurrences around Kutigi Central Bida Basin, Nigeria. Ethiopian J. Environ. Stud. Manage., 3: 49-56.

Akinola, O. Oluwatoyin, Ademilua and L. Oladimeji, 2014. Compositional features and functional industrial applications of the lateritic clay deposits in Oye-Ekiti and Environs, Southwestern Nigeria. Intl. J. Sci. Technoledge, 2: 6-12.

Alao, D.A., 1983. Geology and engineering properties of laterites from Ilorin, Nigeria. Eng. Geol., 19: 111-118

BS, 1990. Methods of Test for Soils for Civil Engineering Purposes. Vol. 1377. British Standards Institution, London.

Bakker, W.T., 1993. Refractories for present and future electric power plants. Key Eng. Mater., 88: 41-70.

Benson, C.H., H. Zhai and X. Wang, 1994. Estimating hydraulic conductivity of compacted clay liners. J. Geotechnical Eng., 120: 366-387.

Daniel, D.E., 1991. Soils Used in Cover Systems. In: Design and Construction of RCRA/CERCLA Final Covers, Daniel, D.E. (Ed.). United States Environmental Protection Agency, Cincinnati, Ohio, pp: 9-25.
Daniel, D.E., 1993. Clay Liners. In: Geotechnical Practice for Waste Disposal, Daniel, D.E. (Ed.). Chapman \& Hall, London, England, UK., ISBN:9780412351709, pp: 137-163.

Dogan, C.P., K.S. Kwong, J.P. Bennett, R.E. Chinn and C.L. Dahlin, 2002. Improved refractory materials for slagging coal gasifiers. Proceedings of the $27 \mathrm{th}$ International Technical Conference on Coal Utilization \& Fuel Systems, March 4-7, 2002, Sheraton Sand Key Resort, Clearwater, Florida, USA., pp: 1167-1176.

Fakolujo, O.S., O.S. Olokode, P.O. Aiyedun, Y.T. Oyeleke and B.U. Anyanwu et al., 2012. Studies on the five (5) selected clays in Abeokuta, Nigeria. Pac. J. Sci. Technol., 13: 83-90.

Folagbade, S.O., 2001. Case studies of building collapse in Nigeria. Proceedings of the Workshop on Building Collapse, Causes, Prevention and Remedies, October 23-24, 2001, The Nigerian Institute of Building, Ondo State, Nigeria, Pages: 1-24.

Grim, R.E., 1968. Applied Clay Mineralogy. McGraw Hill, London, UK., ISBN:9780835756754, Pages: 596.

Ige, O., B. Durotoye and A.E. Oluyemi, 2005. Mineralogy and geochemistry of lateritic weathering profiles on ultramafic rock bodies around Mokuro in Ile-Ife area, Southwestern Nigeria. J. Min. Geol., 41: 11-18.

Ige, $0.0 ., 2009$. Assessment of geotechnical properties of migmatite-derived residual soil from Ilorin, Southwestern Nigeria, as barrier in sanitary landfill. Cont. J. Earth Sci., 4: 23-33.

Irabor, P.S.A., 2002. Physical and chemical investigation on some Nigerian kaolinite clays for use in the ceramics and allied industries. Niger. J. Eng. Res. Dev., 1: 54-59.

Lambe, T.W. and R.V. Wihteman, 1969. Soil Mechanics. Wiley, New York, USA., ISBN:9780852265031, Pages: 553.

Nnadi, G., 1987. Geotechnical properties of tropical residual soils. Master Thesis, Lulea University of Technology, Lulea, Sweden.

Ogunsanwo, O., 1995. Influence of geochemistry and mineralogy on the optimum geotechnical utilisation of some laterite soils from SW Nigeria. J. Min. Geol., 31: 183-188.

Ogunsanwo, O., 1996. Geotechnical investigation of some soils from S.W. Nigeria for use as mineral seals in waste disposal landfills. Bull. Intl. Assoc. Eng. Geol., 54: 119-123.

Okunlola, O.A., 2008. Compositional characteristics and functional industrial application of Itakpe clay occurrence central Nigeria. Eur. J. Sci. Res., 19: 453-461. 
Olokode, O.S., P.O. Aiyedun, S.I. Kuye, N.O. Adekunle and W.E. Lee, 2013. Evaluation of a clay mineral deposit in Abeokuta, South-West Nigeria. J. Nat. Sci. Eng. Technol., 9: 132-136.

Rowe, R.K., R.M. Quigly and J.R. Booker, 1995. Clayey Barrier Systems for Waste Disposal Facilities. 1st Edn., E and FN SPON, London.
Skempton, A.W., 1953. The colloidal activity of clay. Proceedings of the 3rd International Conference on Soil Mechanics and Foundation Engineering, August 16-27, 1954, ICOSOMEF Publisher, Zurich, Switzerland, pp: 57-61.

Ugbe, F.C., 2011. Effect of multicyclic compaction on cohesion in lateritic soils. Arch. Appl. Sci. Res., 3: 115-121. 